\title{
Streptomyces xinghaiensis sp. nov., isolated from marine sediment
}

\author{
Xin-Qing Zhao, ${ }^{1}$ Wen-Jun Li, ${ }^{2,3}$ Wen-Ce Jiao, ${ }^{1}$ Yan Li, ${ }^{2}$ Wen-Jie Yuan, ${ }^{1}$ \\ Yu-Qin Zhang, ${ }^{4}$ Hans-Peter Klenk, ${ }^{5}$ Joo-Won Suh ${ }^{6}$ and Feng-Wu Bai ${ }^{1}$
}

\author{
Correspondence \\ Feng-Wu Bai \\ fwbai@dlut.edu.cn
}

\author{
${ }^{1}$ Department of Bioscience and Bioengineering, Dalian University of Technology, Linggong Road 2, \\ Dalian 116024, PR China \\ ${ }^{2}$ The Key Laboratory for Microbial Resources of the Ministry of Education, and Laboratory for \\ Conservation and Utilization of Bio-resources, Yunnan Institute of Microbiology, Yunnan University, \\ Kunming, Yunnan 650091, PR China \\ ${ }^{3}$ Guangdong Key Laboratory of Marine Materia Medica, South China Sea Institute of Oceanology, \\ Chinese Academy of Sciences, Guangzhou 510301, PR China \\ ${ }^{4}$ Institute of Medicinal Biotechnology, Chinese Academy of Medical Sciences and Peking Union \\ Medical College, Beijing 100050, PR China \\ ${ }^{5} \mathrm{DSMZ}$ - Deutsche Sammlung von Mikroorganismen und Zellkulturen GmbH, 7b Inhoffenstraße, \\ D-38124 Braunschweig, Germany \\ ${ }^{6}$ Department of Biological Science, Myongji University, Yongin 449-728, Republic of Korea
}

Many marine actinobacteria have been screened and identified in recent years (Maldonado et al., 2005; Ward \& Bora, 2006). It has been demonstrated that a diverse assemblage of actinobacteria is present in the marine environment, including marine sediment (Jensen et al.,

The GenBank/EMBL/DDBJ accession number for the 16S rRNA gene sequence of strain $\mathrm{S} 187^{\top}$ is EF577247.

A scanning electron micrograph of strain $\mathrm{S} 187^{\top}$, a phylogenetic tree based on 16S rRNA gene sequences of $S 187^{\top}$ and related strains constructed using the maximum-parsimony method and antimicrobial activities of $S 187^{\top}$ and closely related strains are available as supplementary material with the online version of this paper.
2005; Bredholdt et al., 2007), especially deep-sea sediment (Pathom-Aree et al., 2006), as well as marine sponges (Montalvo et al., 2005; Zhang et al., 2006). Dalian is a coastal city located in the southernmost part of the Liaodong Peninsula, China, which has a very long coastline of $1906 \mathrm{~km}$. However, the possible abundance of marine actinobacteria remains largely unexplored, except for some reports on sponge-derived marine actinobacteria (Zhang et al., 2006). During our screening of marine actinobacteria from sediment samples taken from the sea in the Dalian area, strain $S 187^{\mathrm{T}}$ was recovered from a sediment sample collected from Xinghai Bay. In this study, strain $S 187^{\mathrm{T}}$ was characterized using a polyphasic taxonomic approach; it is 
proposed that this strain represents a novel species of the genus Streptomyces.

Strain $S 187^{\mathrm{T}}$ was isolated from a marine sediment sample from Xinghai Bay, Dalian, China, after 2 weeks incubation at $28{ }^{\circ} \mathrm{C}$ on Bennett's agar (Margalith \& Beretta, 1960). Morphological, physiological and biochemical characterizations of strain $S 187^{\mathrm{T}}$ were carried out following the standard protocol of the International Streptomyces Project (ISP; Shirling \& Gottlieb, 1966, 1968a, b, 1969). Colour determination was assessed by comparison with the colour chips from ISCC-NBS Color Charts standard sample no. 2106 (Kelly, 1964). Formation of spores and mycelia was determined by light microscopy (BH-2; Olympus) and scanning electron microscopy (JSM-5600LV; JEOL) of strain $\mathrm{S}_{187^{\mathrm{T}}}$ grown on ISP medium 2 (ISP 2) at $28{ }^{\circ} \mathrm{C}$ for 4 weeks. Phenotypic properties of strain $S 187^{\mathrm{T}}$ and closely related strains were examined using standard procedures (Shirling \& Gottlieb, 1966; Williams et al., 1983). The effects of various temperatures $\left(4-65^{\circ} \mathrm{C}\right), \mathrm{pH}(4.0-10.0$ at intervals of $1.0 \mathrm{pH}$ unit; determined at $28{ }^{\circ} \mathrm{C}$ ) and $\mathrm{NaCl}$ concentrations $[0,1,2,3,4,5,10,15,20$ and $25 \%(\mathrm{w} / \mathrm{v})$; determined at $28{ }^{\circ} \mathrm{C}$ ] on growth were determined on cells grown on ISP 2 for 3-4 weeks. Antimicrobial activities of strain $S 187^{\mathrm{T}}$ and closely related strains were tested as follows. Cells were grown in tryptone soy broth (Becton Dickinson) at $28{ }^{\circ} \mathrm{C}$ for 6 days, culture broth was then centrifuged at $4{ }^{\circ} \mathrm{C}, 12000$ r.p.m. for $10 \mathrm{~min}$, and $200 \mu \mathrm{l}$ supernatant was applied to agar blocks on the assay plates spread with test strains. The test strains, purchased from the China General Microbiological Culture Collection Center (CGMCC), were Escherichia coli CGMCC 1.797, Staphylococcus aureus CGMCC 1.89, Bacillus subtilis CGMCC 1.1849, Pseudomonas aeruginosa CGMCC 1.2031, Candida albicans CGMCC 2.538 and Aspergillus niger CGMCC 3.2915.

Amino acids and peptides in cell-wall hydrolysates were analysed by the methods described by Hasegawa et al. (1983). Whole-cell sugars were analysed by the methods of Lechevalier \& Lechevalier (1980). Menaquinones and phospholipids were extracted from freeze-dried cells and analysed according to Collins (1985) and Lechevalier et al. (1977). Fatty acid composition was determined according to Sasser (1990).

Table 1. Culture characteristics of strain $S 187^{\top}$ and its most closely related neighbours

Strains: $1, S 187^{\mathrm{T}} ; 2$, S. flavofuscus NRRL B- $8036^{\mathrm{T}} ; 3$, S. albiaxialis DSM $41799^{\mathrm{T}}$. Diffusible pigments were not observed on any of the media listed. Colours were taken from ISCC-NBS Color Charts standard sample no. 2106 (Kelly, 1964). Plates were incubated for 4 weeks at $28{ }^{\circ}$ C. - , No growth.

\begin{tabular}{|c|c|c|c|}
\hline Culture medium & 1 & 2 & 3 \\
\hline \multicolumn{4}{|l|}{ ISP 2} \\
\hline Growth & Good & Good & Good \\
\hline Substrate mycelium & Dark orange yellow & Dark orange yellow & Moderate reddish brown \\
\hline \multicolumn{4}{|l|}{ ISP 3} \\
\hline Growth & Good & Good & Good \\
\hline Substrate mycelium & Yellow white & Strong olive green & Deep orange yellow \\
\hline \multicolumn{4}{|l|}{ Potato-dextrose agar } \\
\hline Growth & Poor & Good & Good \\
\hline Aerial mycelium & - & White & Vivid bluish green \\
\hline Substrate mycelium & Pale orange yellow & Yellow white & Moderate reddish brown \\
\hline \multicolumn{4}{|l|}{ Nutrient agar } \\
\hline Growth & Poor & Moderate & Good \\
\hline Aerial mycelium & - & White & Strong olive green \\
\hline Substrate mycelium & Light yellow brown & Strong olive green & Light yellow brown \\
\hline \multicolumn{4}{|l|}{ ISP 5} \\
\hline Growth & Good & Good & Good \\
\hline Aerial mycelium & Vivid bluish green & White & Vivid yellowish pink \\
\hline Substrate mycelium & Yellow white & Pale orange yellow & Moderate reddish brown \\
\hline \multicolumn{4}{|l|}{ ISP 4} \\
\hline Growth & Good & Good & Good \\
\hline Aerial mycelium & White & White & Deep olive green \\
\hline Substrate mycelium & Pale orange yellow & Yellow white & Pale orange yellow \\
\hline
\end{tabular}


Genomic DNA was extracted as described by Lee et al. (2003) and the 16S rRNA gene was amplified according to Zhang et al. (2006). The DNA G + C content of strain $\mathrm{S} 187^{\mathrm{T}}$ was determined by using the HPLC method (Mesbah et al., 1989). Closely related reference strains were chosen from BLAST (Altschul et al., 1997) search results. Phylogenetic analysis was performed using the software package MEGA version 2.1 (Kumar et al., 2001) after multiple alignment using CLUSTAL_X (Thompson et al., 1997). A phylogenetic tree was reconstructed using the neighbour-joining method (Saitou \& Nei, 1987). The topology of the phylogenetic tree was evaluated by using the bootstrap resampling method of Felsenstein (1985) with 1000 replicates.

Morphological observation of a 28-day-old culture of strain $S 187^{\mathrm{T}}$ grown on ISP 2 (yeast extract-malt extract agar) revealed that strain $S 187^{\mathrm{T}}$ had the typical characteristics of members of the genus Streptomyces. Aerial mycelium and substrate mycelium were well-developed without fragmentation. Long spore chains were straight or flexuous and spores were smooth and non-motile (see Supplementary Fig. S1, available in IJSEM Online). Strain $\mathrm{S}_{187^{\mathrm{T}}}$ grew well between $\mathrm{pH} 6.0$ and 9.0, with optimum growth at $\mathrm{pH} 7.0-8.0$. It grew at $10-45{ }^{\circ} \mathrm{C}$, with optimum growth at $28{ }^{\circ} \mathrm{C}$. Strain $\mathrm{S} 87^{\mathrm{T}}$ grew in the presence of 0 $9 \%(\mathrm{w} / \mathrm{v}) \mathrm{NaCl}$. Mycelia of strain $\mathrm{S} 187^{\mathrm{T}}$ were well- developed on some media tested, including ISP 2, ISP 3 (oatmeal agar), ISP 5 (glycerol-asparagine agar) and ISP 4 (inorganic salts-starch agar), but growth was poor on nutrient agar, Czapek's agar and potato-dextrose agar (Table 1). No diffusible pigments were observed on any media tested.

The cell wall of strain S187 ${ }^{\mathrm{T}}$ contained LL-diaminopimelic acid and glycine (cell-wall chemotype I; Lechevalier \& Lechevalier, 1970). Whole-cell hydrolysates contained mainly ribose, glucose and galactose, with a small amount of mannose. Phospholipids of strain $S 187^{\mathrm{T}}$ were phosphatidylethanolamine, phosphatidylinositol, phosphatidylglycerol, phosphatidylinositol mannosides and one unknown phospholipid. The predominant menaquinones were MK$9\left(\mathrm{H}_{6}\right) \quad(40.8 \%)$, MK-9 $\left(\mathrm{H}_{8}\right) \quad(38.2 \%)$ and MK-9 $\left(\mathrm{H}_{2}\right)$ $(8.8 \%)$. The major fatty acids found were iso- $\mathrm{C}_{16: 0}$ $(29.2 \%)$, anteiso- $\mathrm{C}_{15: 0}(14.0 \%)$, anteiso- $\mathrm{C}_{17: 0}(11.6 \%)$, iso- $\mathrm{C}_{14: 0}(8.8 \%)$, iso- $\mathrm{C}_{15: 0}(5.5 \%)$, iso- $\mathrm{C}_{16: 1} \mathrm{H}(4.6 \%)$, anteiso- $\mathrm{C}_{17: 1} \mathrm{C}(4.0 \%), \mathrm{C}_{16: 0}(4.0 \%)$ and iso- $\mathrm{C}_{17: 0}$ (3.5\%). All morphological characteristics and chemotaxonomic data showed that strain $S 187^{\mathrm{T}}$ should be assigned to the genus Streptomyces.

The almost-complete 16S rRNA gene sequence (1490 nt) of strain $\mathrm{S} 187^{\mathrm{T}}$ was aligned manually with corresponding $16 \mathrm{~S}$ rRNA gene sequences of representative type strains of members of the genus Streptomyces retrieved from

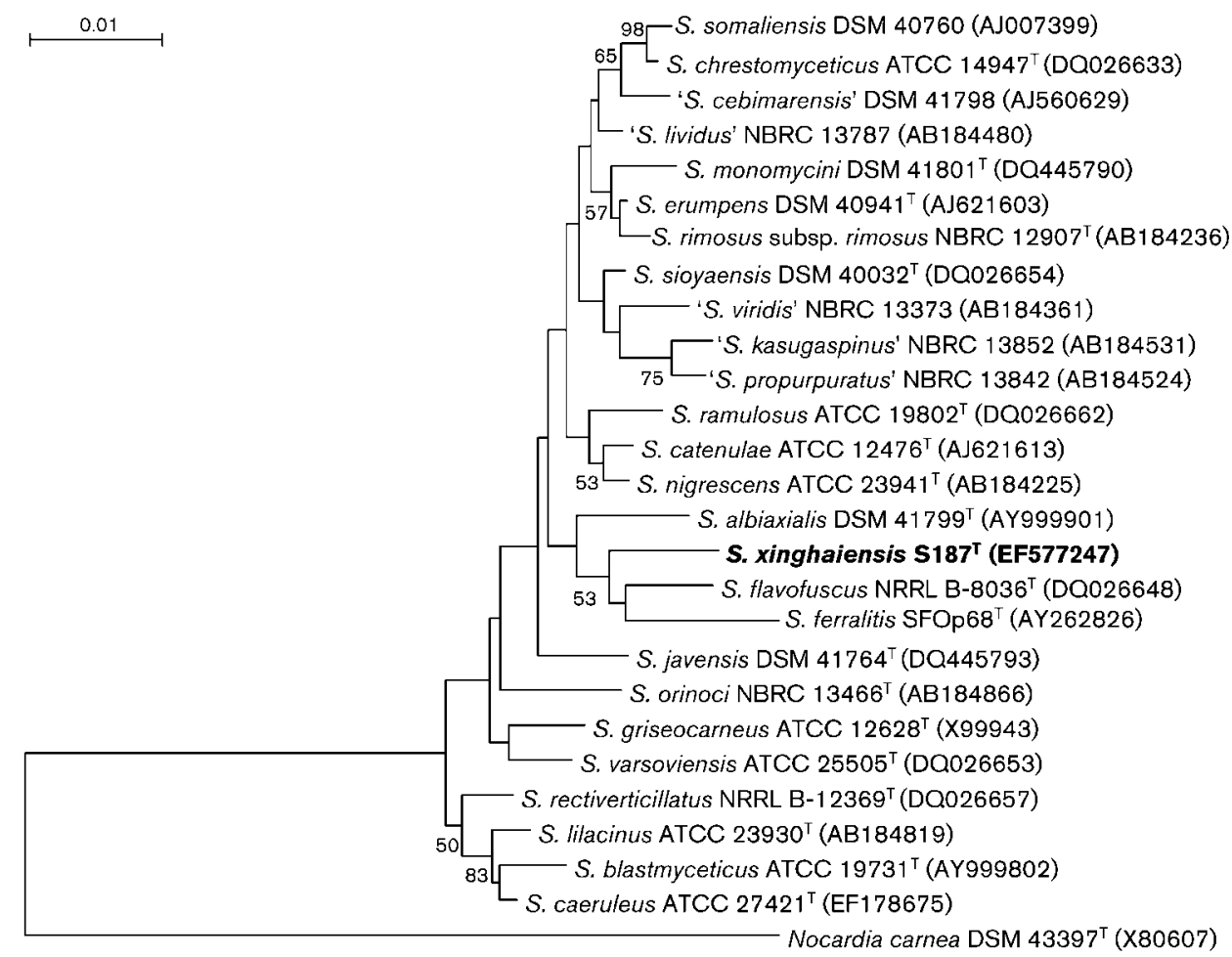

Fig. 1. Phylogenetic tree based on $16 \mathrm{~S}$ rRNA gene sequence analysis and constructed using the neighbour-joining method showing the position of strain $\mathrm{S} 187^{\top}$ among its phylogenetic neighbours. Numbers at the branch nodes are bootstrap values, expressed as percentages of 1000 replicates (only values $>50 \%$ are shown). Bar, 0.01 substitutions per nucleotide position. 
GenBank/EMBL/DDBJ using a BLAST search (http://blast. ncbi.nlm.nih.gov/Blast.cgi; Altschul et al., 1997). Phylogenetic analyses based on 16S rRNA gene sequences showed that the novel isolate fell into one distinct subclade with Streptomyces flavofuscus NRRL B-8036 ${ }^{\mathrm{T}}$ $\left(=\mathrm{DSM} \quad 41426^{\mathrm{T}}\right)$ and Streptomyces albiaxialis DSM $41799^{\mathrm{T}}$, with which it shared $16 \mathrm{~S}$ rRNA gene sequence similarities of 98.1 and $97.5 \%$, respectively. Another closely related strain was Streptomyces ferralitis SFOp $68^{\mathrm{T}}$, which showed $95.6 \% 16 \mathrm{~S}$ rRNA gene sequence similarity (1425 out of $1490 \mathrm{nt}$ ) to strain $\mathrm{S} 187^{\mathrm{T}}$. Phylogenetic trees based on 16S rRNA gene sequences of strain $S 187^{\mathrm{T}}$ and the most closely related type strains of the genus Streptomyces constructed using the neighbour-joining (Fig. 1) and maximum-parsimony (see Supplementary Fig. S2, available in IJSEM Online) methods are shown. DNA-DNA relatedness tests were performed between strain $S 187^{\mathrm{T}}$ and its closest relatives, S. flavofuscus NRRL B-8036 ${ }^{\mathrm{T}}$ and S. albiaxialis DSM $41799^{\mathrm{T}}$, using the optical renaturation method (De Ley et al., 1970; Huß et al., 1983; Jahnke, 1992). The DNA-DNA relatedness values of strain $S 187^{\mathrm{T}}$ with S. flavofuscus NRRL B-8036 ${ }^{\mathrm{T}}$ and $S$. albiaxialis DSM $41799^{\mathrm{T}}$ were 31.4 and $46.9 \%$, respectively, which were significantly lower than $70 \%$, the threshold value for the delineation of genomic species (Wayne et al., 1987). The antimicrobial activities of the three strains were investigated; strain $S 187^{\mathrm{T}}$ displayed excellent activities against the four bacterial strains tested, whereas S. flavofuscus NRRL B- $8036^{\mathrm{T}}$ showed no activity against $P$. aeruginosa (see Supplementary Table S1, available in IJSEM Online). A phenotypic comparison between strain $S 187^{\mathrm{T}}$ and closely related species of the genus Streptomyces was carried out and differential characteristics of the strains were identified (Table 2). On the basis of morphological, chemotaxonomic and phylogenetic evidence and its physiological and biochemical distinctiveness, it is confirmed that strain $S 187^{\mathrm{T}}$ represents a novel species in the genus Streptomyces, for which the name Streptomyces xinghaiensis sp. nov. is proposed.

\section{Description of Streptomyces xinghaiensis sp. nov.}

Streptomyces xinghaiensis (xing.hai.en'sis. N.L. masc. adj. xinghaiensis pertaining to Xinghai Bay, Dalian, China, the site from which the type strain was isolated).

Gram-positive, aerobic and non-motile. Grows well on ISP media 2, 3, 4 and 5, but poorly on nutrient agar, potatodextrose agar and Czapek's agar media (Table 1). Colonies are whitish to yellow with ruffled edges. Aerial mycelium and substrate mycelium are well-developed without fragmentation. Long spore chains are straight or flexuous; spores are smooth and non-motile. Casein, pectin and cellulose are degraded, but starch is not. Positive for catalase production and gelatin liquefaction. No soluble pigments are produced on any media tested. Temperature range for growth is $10-45{ }^{\circ} \mathrm{C}$ (optimum $28{ }^{\circ} \mathrm{C}$ ). Growth occurs at $\mathrm{pH} 6.0-9.0$ and in the presence of $0-9 \% \mathrm{NaCl}$
Table 2. Physiological and biochemical features that differentiate strain $S 187^{\top}$ from closely related species of the genus Streptomyces

Strains: 1 , S187 $7^{\mathrm{T}}$; 2, S. flavofuscus NRRL B- $8036^{\mathrm{T}}$; 3, S. albiaxialis DSM $41799^{\mathrm{T}}$. + , Positive; - , negative.

\begin{tabular}{|c|c|c|c|}
\hline Characteristic & 1 & 2 & 3 \\
\hline \multicolumn{4}{|l|}{ Degradation of: } \\
\hline Casein & + & + & - \\
\hline Cellulose & + & - & + \\
\hline \multicolumn{4}{|c|}{ Growth in $\mathrm{NaCl}(\%, w / v)$ : } \\
\hline Range & $0-9$ & $0-10$ & $0-6$ \\
\hline Optimum & $0-5$ & $0-5$ & $0-3$ \\
\hline Growth at $5{ }^{\circ} \mathrm{C}$ & - & - & + \\
\hline Growth pH & $7-9$ & $6-9$ & $7-9$ \\
\hline \multicolumn{4}{|c|}{ Carbon source utilization: } \\
\hline L-Arabinose & - & - & + \\
\hline Ribose & + & + & - \\
\hline myo-Inositol & - & - & + \\
\hline L-Rhamnose & + & + & - \\
\hline Cellobiose & - & + & + \\
\hline Sorbitol & - & - & + \\
\hline \multicolumn{4}{|c|}{ Nitrogen source utilization: } \\
\hline Lysine & - & + & - \\
\hline Phenylalanine & + & - & + \\
\hline Serine & + & + & - \\
\hline Xanthine & + & + & - \\
\hline
\end{tabular}

(w/v). Good growth is found on almost all nitrogen sources tested. Utilizes D-glucose, sucrose, mannitol, fructose, mannose, galactose, ribose and rhamnose as carbon sources, but not trehalose, L-arabinose, myo-inositol, raffinose, cellobiose or sorbitol. More detailed phenotypic properties are shown in Table 2. Cell wall contains LLdiaminopimelic acid as the diagnostic diamino acid. Whole-cell hydrolysates contain mainly ribose, glucose and galactose, with a small amount of mannose. Chemotaxonomic properties are typical of the genus Streptomyces.

The type strain, $S 187^{\mathrm{T}}\left(=\mathrm{NRRL} \mathrm{B}-24674^{\mathrm{T}}=\mathrm{CCTCC}\right.$ AA $208049^{\mathrm{T}}=$ KCTC $19546^{\mathrm{T}}$ ), was isolated from a marine sediment sample collected from Xinghai Bay, Dalian, Liaoning Province, China. The DNA G $+\mathrm{C}$ content of the type strain is $72.01 \mathrm{~mol} \%$.

\section{Acknowledgements}

X.-Q.Z. is grateful for the support of the Alexander von Humboldt Foundation for her research stay at University of Tübingen in Germany. W.-J. L. was supported by the Program for New Century Excellent Talent in University (NCET).

\section{References}

Altschul, S. F., Madden, T. L., Schäffer, A. A., Zhang, J., Zhang, Z., Miller, W. \& Lipman, D. J. (1997). Gapped BLAST and PSI_BLAST: a new 
generation of protein database search programs. Nucleic Acids Res 25, 3389-3402.

Bredholdt, H., Galatenko, O. A., Engelhardt, K., Fjærvik, E., Terekhova, L. P. \& Zotchev, S. B. (2007). Rare actinomycete bacteria from the shallow water sediments of the Trondheim fjord, Norway: isolation, diversity and biological activity. Environ Microbiol 9, 27562764.

Collins, M. D. (1985). Isoprenoid quinone analysis in classification and identification. In Chemical Methods in Bacterial Systematics, pp. 267-287. Edited by M. Goodfellow \& D. E. Minnikin. London: Academic Press.

De Ley, J., Cattoir, H. \& Reynaerts, A. (1970). The quantitative measurement of DNA hybridization from renaturation rates. Eur $J$ Biochem 12, 133-142.

Felsenstein, J. (1985). Confidence limits on phylogenies: an approach using the bootstrap. Evolution 39, 783-791.

Hasegawa, T., Takizawa, M. \& Tanida, S. (1983). A rapid analysis for chemical grouping of aerobic actinomycetes. J Gen Appl Microbiol 29, 319-322.

Huß, V. A. R., Festl, H. \& Schleifer, K. H. (1983). Studies on the spectrophotometric determination of DNA hybridization from renaturation rates. Syst Appl Microbiol 4, 184-192.

Jahnke, K. D. (1992). BASIC computer program for evaluation of spectroscopic DNA renaturation data from GILFORD SYSTEM 2600 spectrophotometer on a PC/XT/AT type personal computer. J Microbiol Methods 15, 61-73.

Jensen, P. R., Gontang, E., Mafnas, C., Mincer, T. J. \& Fenical, W. (2005). Culturable marine actinomycete diversity from tropical Pacific Ocean sediments. Environ Microbiol 7, 1039-1048.

Kelly, K. L. (1964). Inter-Society Color Council - National Bureau of Standard Color Name Charts Illustrated with Centroid Colors. Washington, DC: US Government Printing Office.

Kumar, S., Tamura, K., Jakobsen, I. B. \& Nei, M. (2001). MEGA2: molecular evolutionary genetics analysis software. Bioinformatics 17, 1244-1245.

Lechevalier, M. P. \& Lechevalier, H. A. (1970). Chemical composition as a criterion in the classification of aerobic actinomycetes. Int J Syst Bacteriol 20, 435-443.

Lechevalier, M. P. \& Lechevalier, H. A. (1980). The chemotaxonomy of actinomycetes. In Actinomycete Taxonomy, pp. 227-291. Edited by A. Dietz \& D. W. Thayer. Arlington, VA: Society for Industrial Microbiology.

Lechevalier, M. P., De Bièvre, C. \& Lechevalier, H. A. (1977). Chemotaxonomy of aerobic actinomycetes: phospholipid composition. Biochem Syst Ecol 5, 249-260.

Lee, Y. K., Kim, H. W., Liu, C. L. \& Lee, H. K. (2003). A simple method for DNA extraction from marine bacteria that produce extracellular materials. J Microbiol Methods 52, 245-250.

Maldonado, L. A., Stach, J. E., Pathom-Aree, W., Ward, A. C., Bull, A. T. \& Goodfellow, M. (2005). Diversity of cultivable actinobacteria in geographically widespread marine sediments. Antonie van Leeuwenhoek 87, 11-18.

Margalith, P. \& Beretta, G. (1960). Rifamycin XI: taxonomic study on Streptomyces mediterranei nov. sp. Mycopathol Mycol Appl 13, 321330.

Mesbah, M., Premachandran, U. \& Whitman, W. B. (1989). Precise measurement of the $\mathrm{G}+\mathrm{C}$ content of deoxyribonucleic acid by highperformance liquid chromatography. Int J Syst Bacteriol 39, 159-167.

Montalvo, N. F., Mohamed, N. M., Enticknap, J. J. \& Hill, R. T. (2005). Novel actinobacteria from marine sponges. Antonie van Leeuwenhoek 87, 29-36.

Pathom-Aree, W., Stach, J. E., Ward, A. C., Horikoshi, K., Bull, A. T. \& Goodfellow, M. (2006). Diversity of actinomycetes isolated from Challenger Deep sediment $(10,898 \mathrm{~m})$ from the Mariana trench. Extremophiles 10, 181-189.

Saitou, N. \& Nei, M. (1987). The neighbor-joining method: a new method for reconstructing phylogenetic trees. Mol Biol Evol 4, 406425.

Sasser, M. (1990). Identification of bacteria by gas chromatography of cellular fatty acids. USFCC Newsl 20, 16.

Shirling, E. B. \& Gottlieb, D. (1966). Methods for characterization of Streptomyces species. Int J Syst Bacteriol 16, 313-340.

Shirling, E. B. \& Gottlieb, D. (1968a). Cooperative description of type cultures of Streptomyces. II. Species descriptions from first study. Int J Syst Bacteriol 18, 69-189.

Shirling, E. B. \& Gottlieb, D. (1968b). Cooperative description of type cultures of Streptomyces. III. Additional species descriptions from first and second studies. Int J Syst Bacteriol 18, 279-392.

Shirling, E. B. \& Gottlieb, D. (1969). Cooperative description of type cultures of Streptomyces. IV. Species descriptions from the second, third and fourth studies. Int J Syst Bacteriol 19, 391-512.

Thompson, J. D., Gibson, T. J., Plewniak, F., Jeanmougin, F. \& Higgins, D. G. (1997). The CLUSTAL_X windows interface: flexible strategies for multiple sequence alignment aided by quality analysis tools. Nucleic Acids Res 25, 4876-4882.

Ward, A. C. \& Bora, N. (2006). Diversity and biogeography of marine actinobacteria. Curr Opin Microbiol 9, 279-286.

Wayne, L. G., Brenner, D. J., Colwell, R. R., Grimont, P. A. D., Kandler, O., Krichevsky, M. I., Moore, L. H., Moore, W. E. C., Murray, R. G. E. \& other authors (1987). International Committee on Systematic Bacteriology. Report of the ad hoc committee on reconciliation of approaches to bacterial systematics. Int J Syst Bacteriol 37, 463-464.

Williams, S. T., Goodfellow, M., Alderson, G., Wellington, E. M. H., Sneath, P. H. A. \& Sackin, M. J. (1983). Numerical classification of Streptomyces and related genera. J Gen Microbiol 129, 1743-1813.

Zhang, H., Lee, Y. K., Zhang, W. \& Lee, H. K. (2006). Culturable actinobacteria from the marine sponge Hymeniacidon perleve: isolation and phylogenetic diversity by $16 \mathrm{~S}$ rRNA gene-RFLP analysis. Antonie van Leeuwenhoek 90, 159-169. 